DOI 10.15276/imms.v10.no1-2.5

\title{
FEATURES OF CREATING INFORMATION TECHNOLOGIES FOCUSED ON THE RESEARCH OF DIFFUSION PROCESSES
}

\author{
O.V. Pyvovar, S.A. Polozhaenko
}

Odessa National Polytechnic University,

1, Shevchenko Ave., Odessa, 65044, Ukraine; e-mail: sanp277@gmail.com

\begin{abstract}
The need to use information technology is due to many reasons. The current state of computer technology (CT), modern numerical methods make it possible to model objects whose behavior is described by very complex mathematical dependencies, for example, nonlinear systems of differential or integral equations. But complex computational algorithms have their own intrinsic properties, which are far from always analogous, even up to approximation errors, to the properties of the original mathematical model (MM). This can lead to effects of a purely computational nature. Therefore, an important task of the theory of numerical methods is (in relation to the considered structure of information technology (IT)) the development of computational algorithms that exclude or minimize the occurrence of such situations. At the same time, the problem of developing an adequate mathematical model for describing various diffusion processes (DP), as well as methods that implement them, remains very urgent. IT must ensure the "liberation" of a human researcher from performing labor-intensive unproductive operations of the computational process. In this article, issues related to the form of representation of solutions obtained in the course of mathematical modeling are considered. The introduction of the computational experiment method into the practice of theoretical research and a wide range of technologies for processing experimental data made it possible to solve fundamentally new problems, and, in some cases, led to the emergence of new subject areas that could not exist before the advent of modern CT and the development of IT.
\end{abstract}

Keywords: multimedia information technology, diffusion process, mathematical modeling, computational experiment.

\section{Introduction}

The main circle of problems solved in the course of mathematical modeling is the development of mathematical models (MM) of the studied processes, as well as the development of computational and numerical methods for the implementation of these MM. Anomalous diffusion is a diffusion process when the classical Einstein relationship is violated, that is, the standard deviation of the position of a wandering particle is not a linear function of time. In practice, many diffusion processes are actually anomalous. In the existing literature, there are many theoretical calculations for describing anomalous diffusions (the method of reducing partial differential equations to ordinary ones, followed by the numerical solution of modeling and identification problems; the method of quasi-linearization and sweep in a parameter; the method of conjugate functions), as well as descriptions of MM variants, but always large of interest is the most accurate and, in practice, easily used MM of anomalous diffusion.

At the same time, issues related to the form of representation of solutions obtained in the course of mathematical modeling should also be recognized as important. First of all, this aspect concerns the application of information technology (IT) and is associated with the presentation, analysis and implementation of the resulting solutions. It is the implementation in a practical way, as well as the IT requirements for the implementation of MM, that is proposed in this article. 
The aim of the work is to identify and analyze the basic requirements for information technology, focused on the presentation of the results of mathematical modeling of diffusion (including the so-called "anomalous") processes.

To achieve this target, it is necessary to solve the following tasks:

- to define and to analyze the tasks facing information technologies in the mathematical modeling of processes;

- to justify the need to use information technology;

- to identify the requirements for information technologies for solving problems of mathematical modeling of the diffusion process.

\section{Main part}

The problems arising (as noted above) in the interpretation of the results of mathematical modeling are, in particular, the following. In a number of important applied cases, in the course of mathematical modeling, the investigated diffusion processes (DP) are considered as processes with distributed parameters. The spatial domain of processes with distributed parameters in modeling is represented by a finite-dimensional mesh of nodes [1-3] or finite elements $[4,5]$, and the state function is an array of values of grid functions at these nodes (or functions in finite elements). Depending on the required accuracy of the solution, the resulting arrays of grid functions (functions in finite elements) have significant sizes $\left(10^{2} \ldots 10^{5}\right.$ values). With such a number of values, the possibilities for interpreting solutions become of paramount importance (for example, ordering arrays of values and their forms of presentation, methods of storage and handling, transformation, etc.).

In addition, the results of mathematical modeling are often only an intermediate link in the applied problem being solved. In particular, when solving problems of controlling technological or natural processes (technical objects), as a result of mathematical modeling, a function of the state of the object is obtained, according to which the control action is synthesized (taking into account the control law). In this case, as a rule, the synthesis of the control action should be carried out in a real (or even in an accelerated) time scale in the case of solving optimization or multivariate problems. Taking into account the fact that technological or natural processes (technical objects), as noted earlier, are mainly processes with distributed parameters (objects with distributed parameters) (with their inherent features and complexities of mathematical modeling and, above all, significant sizes of arrays that determine the values functions of state), then rational methods of data processing acquire a priority. In these conditions, IT, focused on the creation and application of methods and tools for processing the results of mathematical modeling, constitutes an urgent scientific and applied technical problem.

The formation of a wide class of modern theoretical and applied areas of scientific research (associated, for example, with the atmosphere, the extraction of minerals and other physically complex processes and objects in which a certain kind of diffusion anomalies arise) has become fully possible only thanks to the advent of computer modeling. Examples of the most important areas of research in which mathematical (computer) modeling plays a major role are, in particular, problems of numerical weather prediction, climate change and issues related to pollution of the atmosphere and other components of the environment.

The need to use IT in this case is due to a number of reasons:

- equations describing various processes cannot be solved analytically without using numerical methods, the implementation and interpretation of which is due to the use of IT tools;

- modeling of the specified class of processes is associated with a huge amount of computations, which often requires the use of the most powerful means of CT and developed IT; 
- the only experimental data on the state of complex processes are the data of numerous observations (for example, for geological processes, this is drilling wells and measuring reservoir pressures in them; for processes in the atmosphere, this is the determination of the characteristics of its state using ground stations, weather balloons, aviation, various remote control systems sounding based on ground-based radars and orbiting satellites), and the assimilation of such an extensive set of data from various sources is impossible without the use of modern systems for processing, collecting and transmitting information;

- modeling (including mathematical) implies manipulation of significant amounts of intermediate data and analysis (for example, systematization, long-term forecast, etc.) of the results obtained, the effective implementation of which is impossible without the use of certain IT;

- a number of problems of mathematical modeling (especially in the field of studying the regional and global climate; seismic exploration, geodesy and geoecology; variational assimilation of data in complex technological processes) is associated with the need to maintain huge data archives, constant and effective access to which must be provided by IT means.

If we consider mathematical modeling in conjunction with the IT that implements it, then, in this case, it is permissible to talk about information and mathematical modeling (IM modeling) [4, 6]. In this case, the process of IM-modeling includes: collection of the necessary information (in accordance with the set goal), which constitutes (determines) the information model of the process (object) under study; processing of the received data (their organization or structuring) and the algorithm for transforming this data (encapsulation); formation of MM process (object); geometrization of the model or its results of computational implementation (computer visualization by means of computer graphics - the execution of geometric constructions).

Thus, we can conclude that IT provides, in solving problems of mathematical modeling, in the narrow sense, preparation (and, if necessary, collection, as, for example, in the case of modeling atmospheric processes) of the initial data and interpretation of the solution results in a convenient form. or, in a broader sense, IT acts as a toolkit for the implementation of methods and means of mathematical modeling, constituting, in conjunction with the latter, the basis of IM modeling, in which IT and mathematical modeling tools most effectively complement each other in the course of solving applied problems.

The most important factor that determines the effectiveness of IT is its structure (i.e. the elements that make up IT, and the topological connections between them).

Academician AA Samarsky proposed IT [6, 7], the structure of which (Fig. 1) most fully meets the goal of solving problems of mathematical modeling. At the same time, the IT structure is presented in the form of the "MODEL - ALGORITHM - PROGRAM" structure, which defines an unambiguous action plan for the use of mathematical modeling methods:

- choice (or construction) of an "equivalent" of an object, reflecting in mathematical form its most important properties - the laws to which it obeys, the connections inherent in its constituent parts, etc. (in other words, the essence of MM);

- selection (or development) of an algorithm for implementing the model on PC;

- creation of programs that "translate" MM and the algorithm into an accessible PC language.

The following should be noted regarding the properties of this structure. MM - as the most important link in the structure - must be adequate to the object (process) under study. This should be confirmed by an experiment of one kind or another (that is, the "behavior" of a real object (process) and its MM under equal conditions should coincide). After establishing the adequacy of the structure to the original object with MM, various "experiments" are carried out: computational experiments that give all the required qualitative and quantitative properties and characteristics of the object (process). 


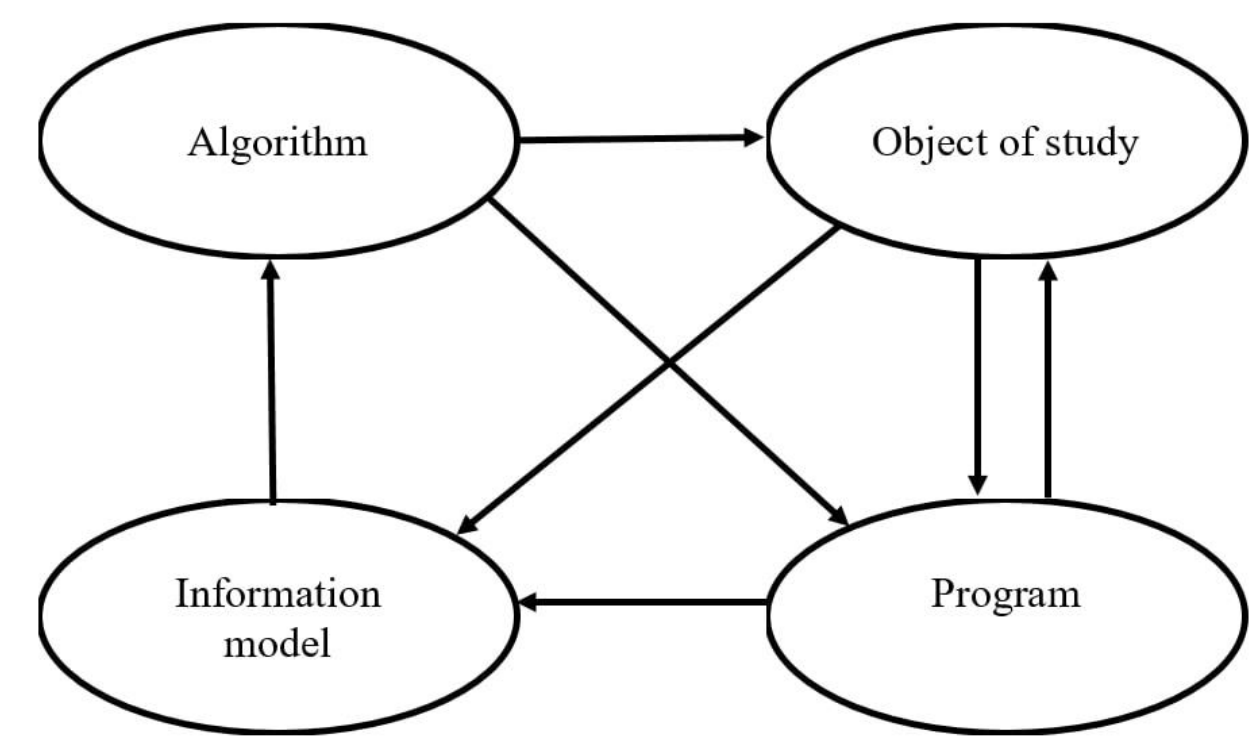

Fig. 1. IT structure focused on solving problems of mathematical modeling (typical structure)

A computational experiment is designed to study, predict, optimize complex (including multiparameter and nonlinear objects (processes)), the theoretical and experimental study of which is difficult by traditional methods.

A computational experiment, in contrast to experiments on natural objects (processes), allows one to accumulate the results obtained in the study of a certain range of problems, and then quickly and flexibly apply them to solving problems in completely different areas. This property is possessed by "universal" MMs that formalize most of the DP. For example, the equation of nonlinear thermal conductivity is suitable for describing not only thermal processes, but also diffusion of matter, movement of groundwater, and gas filtration in porous media. Only the physical meaning of the quantities included in this equation changes. The modeling process is accompanied by the improvement and refinement, as necessary, of all links of the structure.

It should be noted that programs that implement computational algorithms play an important role in the above structure. They must ensure the efficiency of solving a mathematical problem with a minimum of computational costs.

Thus, IT supporting a computational experiment, in their structure, include: methods for constructing MM, support for the latest implementations for finding and selecting algorithms and programs for numerical solution of problems, methods and tools for the accuracy of the calculations performed and the correct operation of the programs used.

Considering the above, the IT structure shown in Fig. 1, can be taken as a typical (generalized) one, which is focused on solving problems of mathematical modeling, since it covers all the main aspects of solving the specified class of problems. On the basis of a typical IT structure, IT structures are formed, designed to solve applied problems of mathematical modeling.

Analysis of the basic requirements for information technology focused on solving problems of mathematical modeling of diffusion processes

It is obvious that IT that provide the solution of a certain class of problems of mathematical modeling (in particular, modeling of diffusion processes) must meet certain requirements. These requirements reflect the relationship between the main (basic) properties of objects, processes; phenomena investigated in the course of mathematical modeling with the means of applied IT and, ultimately, determine the effectiveness of the latter.

Let's analyze the basic requirements for IT, focused on solving problems of mathematical modeling of diffusion processes. The following requirements are considered basic in the mathematical modeling of diffusion processes: 
- the ability to process large-scale arrays of numerical information, which are fields of values of the required functions of the state of the DP. Moreover, this processing should provide both operations on multidimensional (mainly two- and three-dimensional) arrays, and the possibility of obtaining a result in real (or even accelerated) time scale, taking into account the subsequent solution of multivariate and optimization control problems;

- the ability to adequately display the qualitative dynamic behavior of the DP at the stage of visualization of the solution of mathematical modeling problems, taking into account the predominantly distributed nature of the processes under study. In other words, when visualizing the received (or displayed) with the help of one or another IT solutions, the latter should be adequate, i.e. with an accuracy to full-scale experiments on a real object (process), reflect its dynamic behavior, taking into account the action on the object (process) of external disturbances and controls;

- creation of effective (from the point of view of computational costs) numerical methods for the implementation of the MM DP in the procedures of IM-modeling. The complexity of the formalization of the problems of mathematical modeling of DP, caused by the finite unrepresentability of the MM of the DP, the nontrivial nature of the spatial regions of modeling and boundary conditions, imposes increased requirements on the computational costs of the computer implementation of the methods used as part of the IT used. Ultimately, the computational costs for the implementation of mathematical modeling methods determine the influence of these methods (as an integral part of the IM-modeling technology) under the conditions of the given criteria;

- the ability to automate the process of mathematical modeling of DP. IT should free the researcher from performing time-consuming operations of the computational process. For example: setting geometry and discretizing spatial areas; determination of parameters of discrete spatial areas; recalculation and re-assignment of these parameters in the course of solving non-stationary and non-linear problems; assignment, recalculation and input of initial and boundary conditions, etc. The human researcher, if necessary, retains the functions of analysis and decision-making based on the results of mathematical modeling.

\section{Conclusion}

The basic requirements for IT focused on solving problems of mathematical modeling of diffusion processes are stated. Possible ways of increasing the efficiency of these ITs in the course of applied research are shown, and the possibility of interpreting the typical IT structure for solving scientific and engineering problems is analyzed.

\section{References}

1. Верлань А.Ф., Положаенко С.А., Сербов Н.Г. Математическое моделирование процессов аномальной диффузии. Киев: Наукова думка, 2011. 416 с.

2. Бусленко Н.П. Моделирование сложных систем. Москва:Наука, 2001. 374c.

3. Коздоба Л.А. Электрическое моделирование явлений тепломассопереноса. Москва: Энергия, 1972. 296 с.

4. Згуровский М.З., Мельник В.С., Новиков А.Н. Прикладные методы анализа и управления нелинейными процессами и полями. Киев: Наукова думка, 2004. 588 с.

5. Мацевитый Ю.М., Прокофьев В.Е. Моделирование нелинейных процессов в распределенных системах. Киев: Наукова думка, 1985. 302 с.

6. Самарский А.А., Михайлов А.П. Компьютеры и жизнь: Математическое моделирование. Москва: Педагогика, 1987. 157 с.

7. Самарский А.А., Михайлов А.П. Математическое моделирование: Идеи. Методы. Примеры. Москва: Физматлит, 2005. 265 с. 


\title{
ОСОБЕННОСТИ СОЗДАНИЯ ИНФОРМАЦИОННЫХ ТЕХНОЛОГИЙ, ОРИЕНТИРОВАННЫХ НА ИССЛЕДОВАНИИ ДИФФУЗИОННЫХ ПРОЦЕССОВ
}

\author{
О.В. Пивовар, С.А. Положаенко
}

Одесский национальный политехнический университет, просп. Шевченко, 1, Одесса, 65044, Украина; e-mail: sanp277@gmail.com

Необходимость использования информационной технологии обусловлена множеством причин. Нынешнее состояние вычислительной техники (ВТ), современных численных методов позволяют осуществлять моделирование объектов, поведение которых описывается весьма сложными математическими зависимостями, например, нелинейными системами дифференциальных или интегральных уравнений. Но сложные вычислительные алгоритмы обладают своими внутренними свойствами, которые далеко не всегда аналогичны, даже с точностью до ошибок аппроксимации, свойствам исходной математической модели (ММ). Это может приводить к появлению эффектов, имеющих чисто вычислительную природу. Поэтому важной задачей теории численных методов является (применительно к рассматриваемой структуре информационной технологии (ИТ)) разработка вычислительных алгоритмов, исключающих или сводящих к минимуму появление подобных ситуаций. При этом проблема разработки адекватных ММ для описания различных диффузионных процессов (ДП), а также методов, их реализующих, остается весьма актуальной. ИТ должна обеспечить «освобождение» человекаисследователя от выполнения трудоемких непроизводительных операций вычислительного процесса. В статье, рассмотрено вопросы, связанные с формой представления получаемых в ходе математического моделирования решений. Внедрение метода вычислительного эксперимента в практику теоретических исследований и широкого спектра технологий обработки экспериментальных данных позволило решить принципиально новые задачи, а, в ряде случаев, привело и к возникновению новых предметных областей, существование которых было невозможно до появления современных средств ВТ и развития ИТ.

Ключевые слова: мультимедийная информационная технология, диффузионный процесс, математическое моделирование, вычислительный эксперимент.

\section{ОСОБЛИВОСТІ СТВОРЕННЯ ІНФОРМАЦІЙНИХ ТЕХНОЛОГІЙ, ОРІЄНТОВАНИХ НА ДОСЛІДЖЕННЯ ПРОЦЕСІВ ДИФУЗІЇ}

\section{О.В. Пивовар, С.А. Положаєнко}

Одеський національний політехнічний університет, просп. Шевченка, 1, Одеса, 65044, Україна; e-mail: sanp277@gmail.com

Необхідність використання інформаційної технології обумовлена безліччю причин. Нинішній стан обчислювальної техніки (ОТ), сучасних чисельних методів дозволяють здійснювати моделювання об'єктів, поведінка яких описується досить складними математичними залежностями, наприклад, нелінійними системами диференціальних або інтегральних рівнянь. Але складні обчислювальні алгоритми мають свої внутрішні властивості, які далеко не завжди аналогічні, навіть 3 точністю до помилок апроксимації, властивостям вихідної математичної моделі (ММ). Це може призводити до появи ефектів, що мають чисто обчислювальну природу. Тому важливим завданням теорії чисельних методів $є$ (стосовно аналізованої структурі інформаційної технології (ІТ)) розробка обчислювальних алгоритмів, що виключають або зводять до мінімуму появу подібних ситуацій. При цьому проблема розробки адекватних ММ для опису різних дифузних процесів (ДП), а також методів, їх реалізують, залишається досить актуальною. IT повинна забезпечити «звільнення» людини-дослідника від виконання трудомістких непродуктивних операцій обчислювального процесу. У статті, розглянуто питання, пов'язані з формою подання одержуваних в ході математичного моделювання рішень. Впровадження методу обчислювального експерименту в практику теоретичних досліджень і широкого спектру технологій обробки експериментальних даних дозволило вирішити принципово нові завдання, а, в ряді випадків, призвело і до виникнення нових предметних областей, існування яких було неможливо до появи сучасних засобів ОТ і розвитку IT.

Ключові слова: мультимедійна інформаційна технологія, дифузійний процес, математичне моделювання, обчислювальний експеримент. 